\title{
Did I Pass the Test? Middle Eastern Women at Higher Education Learning through Self-Assessment and Reflection
}

\author{
Roslyn Billy, Ph.D \\ Curriculum and Instruction \& ELL Specialist Grand View University \\ Des Moines, Iowa \\ Carmen Medina Garriguez, Ph.D \\ Foundations Program Chair, Higher Colleges of Technology \\ Dubai Men's Campus, Dubai
}

\begin{abstract}
This small-scale study was conducted in order to determine the relationship among the combinations of self-assessment, collaborative activities, and task based learning instruction and academic achievement amid Middle Eastern women at a higher education institution. It describes an experience of educational development within a university context. The study aims to show the effectiveness of the use of selfassessment at higher education in the Middle East among women. Billy and Medina implemented various instructional strategies in four courses over a period of two full semesters. Each of the implanted strategies allowed course participants to take part in self-evaluation. They surveyed course participants to assess the effectiveness of instructional strategies which allow students to self-assess their learning throughout the course. Billy and Medina also found a relationship between self-assessment instructional strategies and the academic achievement of the course participants. The intended audience for this chapter is instructors in the international circuit who would like to read about experiences regarding the implementation of self-assessment, collaborative learning, peer evaluation and task based learning with the intention of putting these strategies into practice in their own context.
\end{abstract}

Keywords: Self-Assessment; Self-Reflection; Academic Achievement; Collaborative Learning; Task Based Learning; Peer Evaluation.

\section{INTRODUCTION}

Peer collaboration, self-evaluation, self-reflection and peer assessment are all affective methods of self-assessment unquestionably used at primary and secondary school levels. Implementing self-assessment techniques at higher education is often considered challenging and time consuming. At the same time, implementing self-assessment techniques at the level of higher education can provide an enriched instructional experience for all learning levels within the college course room. Often, students cannot accurately monitor their progress toward learning goals and overestimate mastery of content, leading to overconfidence and, subsequently, poor academic performance (Bercher, 2012). To achieve learner autonomy among students at any educational level, from primary to higher education, effective self-assessment instructional strategies need to be implemented within the course room. Self-regulation of one's learning allows the student to control their cognitive abilities. Pintrich (2000) described self-regulation as "an active, constructive process" during which students monitor, regulate, and control their cognition, motivation, and behavior, suggesting that motivation as well as cognition is affected by self-regulation.

\section{SELF-ASSESSMENT}

Self-awareness begins at birth and continues until the last breath taken. Awareness of what one knows or does not know falls under the heading of metacognition, the active process of knowing (Bercher, 2012). The process of awareness may begin at birth, but the fostering of that self-awareness process starts at the primary educational level and continues through secondary education. It somehow stops at the higher educational level, and this should not be the case. This small-scale study supports the need for the continuation of self-assessment instructional strategies at the higher educational level. 
Students who are aware of their own cognitive state are able to adjust their performance when warranted (as cited in Bercher, 2012). The more aware students are of their metacognitive abilities, the more likely they are to be aware of their learning.

Self-assessment has positive benefits for students at multiple levels of their educational career. A selfassessment instrument used prior to the study of a given topic or content area can constitute an outstanding diagnostic tool for providing valuable information to the teacher about the student's previous knowledge (Ibabe \& Jauregizar, 2009). Within this small-scale study, the course participants carried out a self-assessment/self-reflection prior to the beginning of each topic covered during the course, which allowed the instructors to assess the ability of their course participants and guide their instruction.

Student reaction: Students were often confused when we presented them with self-assessment/ self-reflection activities. 90\% of the students had not carried out a reflection on their current knowledge within the subjects. They often asked questions regarding the purpose of the self-assessment/self-reflection activities and the compulsoriness of their execution. The remaining $10 \%$ did not carry out the activities.

\section{ACADEMiC ACHIEVEMENT}

Academic achievement represents performance outcomes that indicate the extent to which a person has accomplished specific goals that were the focus of activities in instructional environments, specifically in school, college, and university (Steinmayr et al, 2014). Billy and Medina adapted the syllabus offered by the English Department to include and highlight self-assessment as a predominant cognitive goal, reinforcing critical thinking skills, collaboration and sharing. Academic achievement using the strategies they proposed would cover the widespread criteria that signpost attainment of diverse indicators such as procedural and declarative knowledge or curricular criteria which covers grades and performance.

In the Middle Eastern context in which we carried out this study, the concept of academic achievement is linked to social success and prestige; particularly because it is an all-women academic environment in a male dominated society.

Nonetheless, we must not forget that the success and prestige brought about by academic achievement is not exclusive to Middle Eastern societies, but is also present at international levels in studies such as the Program for International Student Assessment (PISA) carried out by the Organization for Economic Co-operation and Development (OECD).

\section{Peer Evaluation}

Peer evaluation promotes learner autonomy. Learner autonomy is a long standing favorite in foreign language teaching (Yagcioglu, 2015). Taking responsibility for our learning process has been a recent addition to the many innovations which have followed the onset of autonomous learning since Holec (1981:3) coined the term in 1981. Billy and Medina have focused on autonomy as a right and responsibility for learners to determine the direction of their learning (Benson \& Voller 1997:2); as well as on autonomy as a means of lifelong learning or as Watson (2003:3) puts it, "...a continuously supportive process which stimulates and empowers individuals to acquire all the knowledge, values, skills and understanding they will require throughout their lifetimes and to apply them with confidence, creativity and enjoyment in all roles, circumstances and environments."

Research suggests that students need to develop as independent learners in order to be successful in their higher education programs and also in their professional lives post-graduation (Thomas, Martin, $\&$ Pleasants, 2011). There are various methods of peer evaluation, which range from the academic socialization approach, to the general one-on-one peer evaluation. We focused on a general class observation as well as a one-on-one observation.

Student reaction: In our context, the students were hesitant and wary of evaluating one another. Of the 78 students surveyed in English Pronunciation 131, 61\% said they liked peer evaluation while 39\% said they did not. Most of them felt more comfortable when the assessment was carried out anonymously and the grader or graders were only known to the instructor. Despite this important drawback, we proceeded with our idea that peer assessment and self-evaluation would enhance acquisition of the subject matter because the end of semester course reports revealed that $92 \%$ passed the courses; $55 \%$ of them with an average grade of 70 or higher. 


\section{Collaborative \& TASK BASEd Learning}

According to Dufour, Eaker, and Many (2010), creating a collaborative culture is the key to improving student achievement. By introducing collaborative activities, instructors increase the success rate of students meeting the learning outcomes of the course. Collaborative and task-based learning fosters the following learning skills among students: team work, independent learning, communication skills, problem-solving skills, interdisciplinary learning, information-mining skills, and higher-order thinking skills (Othman \& Shah, 2013).

Student reaction: When confronted with the tasks, $70 \%$ of the students complained that working collaboratively was more complicated and that they knew for a fact that there were students who would not carry their weight in the projects.

An example of this was a group of 5 students who were working on an Information Resources (a definition of the subject ensues) project. Two of the students were doing all the work while the other three either did not come to class or were distracted (pretending to use cell phones or computers to find information). The two hardworking students approached Medina to ask what they could do. Medina emailed the individual group members to ask for feedback on their work. One member never got back to her, whilst the other two were obviously lost and did not provide appropriate feedback. Eventually, the group subdivided with the two hardworking students carrying out the project notably well, whereas the other two students had to start from scratch with a subsequent delay in reaching the different stages of the project. The fifth member eventually dropped the course.

When setting up the groups, $42 \%$ chose (close) friends as members of their groups. $32 \%$ said they wanted the instructor to choose the members. The remaining $26 \%$ did not answer the survey question. We administered surveys at the beginning of each course, mid-term and at the end of each semester. The surveys contained questions referring to personal background, academic background, achievements and progress before, during and after each course.

\section{METHOD}

Medina and Mohamed nee Billy (2013), implemented various instructional strategies in four courses over a period of two full semesters. The first trial took place in an intensive academic writing course (ENG 101) which ran from September to January, 2012. Both instructors taught this course. As newcomers to the faculty and context, the instructors teamed up on the common subjects in order to provide academic rigor as well as share the workload. The most logical step for both academic rigor and sharing the materials development was to have a common place and system which would facilitate accessibility for the students; thus, they developed web pages for all the courses they shared as well as for the courses that each taught individually.

After deciding upon the websites as an organizational tool, they developed the procedures and means. The next step was to learn the level of the students. Because they were writing courses, what better way of assessing the students' knowledge and standing point than to have them write, hence, the students' first assignment was a self-evaluation-cum-history of their writing experience.

Student reaction: As mentioned above, students were puzzled when asked to carry out this assignment. Many did not know how to approach it so Billy and Medina gave the students a number of questions that would guide them through the assignment:

When did you start writing? What do you find hardest about writing? How do you plan your writing? Are you a good writer in your native language? Were there any teachers in particular that you remember because they helped you with your writing?

Once the level was established, we designed the course in three subsequent stages: a) Organizing thought processes for which the students were to produce a mind map in order to organize their ideas to produce descriptive and expository essays. b) In the following stage, we provided templates for the five main essay types (expository, classification, compare and contrast, cause and effect, process analysis). Students signed up to produce one of them. During this stage, we also dealt with the importance of revision, re-writing and proof-reading. c) In the final stage, students went back to their writing portfolios and carried out a self-evaluation of the work produced during the semester, comparing the first writing works with the writing produced at this stage. They also carried out an oral presentation as a self-reflection on their work. 
Student reaction: Medina recorded an audio of the self-evaluation and reflections of the students.

Three significant responses were:

a) "I thought I was a good writer until I realized I wasn't organized, nor did I know anything about the different types of essays."

b) "I am very good at writing in Arabic and find it very hard to write in English without thinking in Arabic."

c) "I thought this course would be very easy, then, I started writing and found that it was much harder than just putting ideas on paper; there had to be a structure!"

For the Second Term mark, students chose from a selection of background readings, they created a mind map which was their only reference material on the day of the exam. Dictionaries were not allowed.

For the Final Exam, a similar procedure was followed. However, since the five instructors who shared the subject and their instruction did not follow the same pattern proposed by Medina and Billy, the students were not only allowed the use of the text provided, but also, two alternative topics.

Student reaction: At the end of the semester, according to statistics from Billy and Medina's Course Reports, of the 150 students who took ENG 101, 92\% passed with a grade of 70 or higher. We did not have access to the results of the other instructors.

Following the positive results of this experience, we decided to extend the dynamics to other subjects (Billy-Mohamed and Medina, 2015). ENG 103 was an undergraduate research writing course which aimed at demonstrating a certain understanding of academic concepts involved in research writing. It offered an overall view of the ability to design an academic research paper, the ability to apply concepts of investigating problems in conjunction with presenting academically accepted arguments, using tools such as critical thinking, analyzing, summarizing and synthesizing, within the APA style framework.

ENG 103 was a follow up course from ENG 101 which covered the basic essay types at the undergraduate level.

However, Information Resources (IR101) was a multidisciplinary course in the sense that students could take it at any point in their college track which made it quite demanding for the instructors as they faced mixed ability classes, in the sense that there were students who were about to graduate and had ample research writing experience seated next to freshman students who were taking the undergraduate research writing course (ENG 103) or even the basic essay writing course (ENG 101) depending on the available tracks in their chosen specialization (Law, Interior Design, Architecture, Translation, etc.).

This genuine ragbag of skills coupled with the personal learning difficulties that each student brought to the courses was a demanding scenario for us, that is why we saw the convenience of the websites as an additional instructional tool because they allowed students to advance at their own speed accessing, reviewing and referring back to the materials available on the sites.

Medina transferred the writing model to her phonetics (ENG 131) and phonology (ENG 240) subjects creating a website, used self-evaluation as initial needs analysis; used peer assessment for students to share their knowledge, difficulties and achievements in both subjects.

\section{Student reaction:}

The basic method of initial self-evaluation as a means of needs analysis, followed by project-work which involved students in collaboration, sharing and working together for a common goal, and a common mark which they obtained both via peer assessment and instructor assessment was the prototype we followed in all the subjects.

\section{Transferability and AdAPTABILITY OF THE MODEL}

At the time this article was written, both Billy and Medina had left the Middle Eastern context. Medina had transferred to a government-owned language school in the south of Spain and Billy to Montgomery Community College in the United States. 
Medina: "I am still using the prototype in my current teaching. The transferability and adaptability is available at my current course website: https://sites.google.com/site/c1cmedegginton/.

Unfortunately, despite my conviction regarding the effectiveness of needs analysis via self-evaluation of the students' personal history of the subject being taught; the convenience of peer assessment as an awareness raising tool, and the usefulness of self-assessment as a subject matter mastery tool; the evaluation process which the students are currently undergoing at my school entails a final exam which will pass or fail the students via a common regional exam created by an external examination panel. Students however are comfortable with the model and enjoying evaluating their peers."

Billy: "My experience has slightly differed, as I have used the model within my teacher education courses, by allowing my course participants to self-evaluate throughout the course, and utilize their ability of self-reflection through their learning process. The transference of this model has proven to be successful within my current teaching situation. I am eager to continue the use of the model in future courses."

Both instructors believe their experiences in entirely different contexts, subjects and levels prove the transferability and adaptability of the model.

\section{RESUlts}

We have been working using the above mentioned prototype since 2012. We have documented and published the first two years, including the statistical analysis. Teachers who are interested can view proceedings in more detail in two formerly published articles. They are both included in the reference section at the end of this chapter.

The results obtained by following our prototype have increased the academic success of our students. However, to attain the aforementioned academic rewards, students need to be consistent in the pursuit of the course goals.

\section{Conclusion}

We are constantly adapting and editing the current model in addition to adapting it to the different subjects and contexts. We are convinced of the efficacy of the model. Efficacy that is no doubt due to the combination of students reflecting consistently upon their current and gaining knowledge, a constant self-evaluation, peer assessment and interaction alongside the use of course websites as an additional instructional tool.

Students for their part are engaged when they see they are not alone in their struggles; they are enthused when they see their advancement, and they are encouraged when they see their work rewarded and respected by their peers.

\section{REFERENCES}

Adi, O., \& Uyar, M. (2013). The relationship between self-efficacy, self-regulated learning strategies and achievement: A path model. Journal of Baltic Science Education, 12(1), 21-33.

Benson, P. \&Voller, P. (1997). Autonomy and Independence in Language Learning. London: Longman.

Bercher, D. (2012). Self-monitoring tools and student academic success:when perception matches reality. Journal of College Science Teaching, 41(5), 26-32.

Béres, I., Magyar, T., \&Turcsányi-Szabó, M. (2012). Towards a Personalised, Learning Style Based Collaborative Blended Learning Model with Individual Assessment. Informatics In Education, 11(1), 1-28.

Billy-Mohamed, R. and Medina, C. (2015). Hey, we just learn in a different way: The UDL (Universal Design for Learning) Model at Higher Education in the Middle East. In Journal of Modern Education Review, ISSN 2155-7993, USA. January 2015, Volume 5, No. 1, pp. 39-48 Doi: 10.15341/jmer(2155-7993)/01.05.2015/004.

Dufour, R., Dufour, R., Eaker, R., and Many, T., (2010). Learning By Doing. Solution Tree Press.

Holec, H., (1981). Autonomy and foreign language learning. Oxford: Pergamon. (First published 1979, Strasbourg: Council of Europe). 
Ibabe, I., \&Jauregizar, J. (2010). Online self-assessment with feedback and metacognitive knowledge. Higher Education, 59(2), 243-258. doi: http://dx.doi.org/10.1007/s10734-009-9245-6.

Jenna-Lynn Senger, \&Kanthan, R. (2012). Student evaluations: Synchronous tripod of learning portfolio assessment-self-assessment, peer-assessment, instructor-assessment. Creative Education, 3(1), 155-163. Retrieved fromhttp://search.proquest.com.library.capella.edu/docview /963357452?accountid=27965.

Medina and Mohamed (nee Billy) (2013). Websites and Lectures: Higher Education at a Middle Eastern Women's College. In Journal of Education and Practice. Vol. 4. No.19. 2013.

Othman, N., \&Ahamad Shah, M. (2013). Problem-Based Learning in the English Language Classroom. English Language Teaching, 6(3), 125-134. doi:10.5539/elt.v6n3p125.

Steinmayr, R., Meißner, A., Weidinger, A. F. \& Wirthwein, L. (2014). Academic Achievement. In L. H. Meyer (Ed.) Oxford Bibliographies Online: Education. New York: Oxford University Press.

Thomas, G., Martin, D., \&Pleasants, K. (2011). Using self-and peer-assessment to enhance students' future-learning in higher education. Journal of University Teaching \& Learning Practice, 8(1), 1-17. Retrieved from http://ro.uow.edu.au/jutlp/vol8/iss1/5.

Watson, L. (2003). Lifelong Learning in Australia, Canberra, Department of Education, Science and Training.

Yagcioglu, O. (2015). New Approaches on Learner Autonomy in Language Learning. GlobELT: An International Conference on Teaching and Learning English as an Additional Language, Antalya, Turkey.Retrieved from http://www.sciencedirect.com/science/article/pii/S1877042815045401 